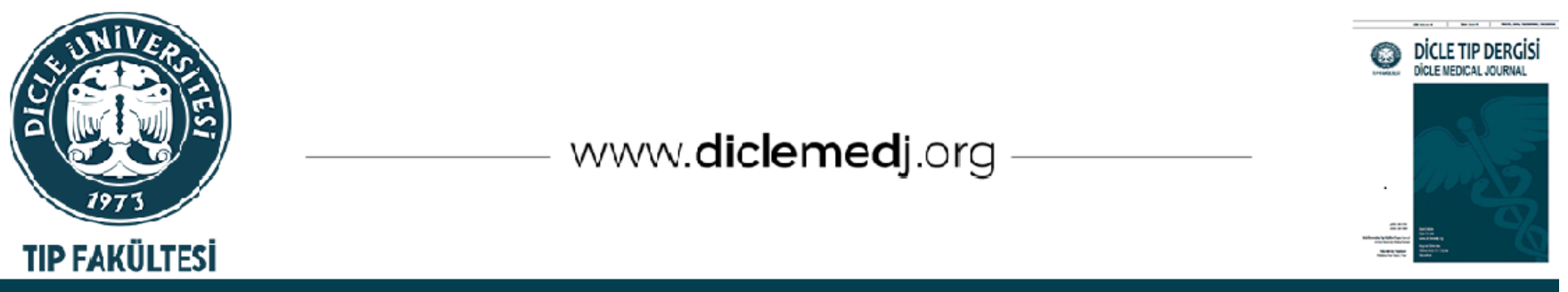

Original Article / Özgün Araştırma

\title{
Measurement of Glomerular Area in Primary Glomerular Diseases With a Digital Pathology Software
}

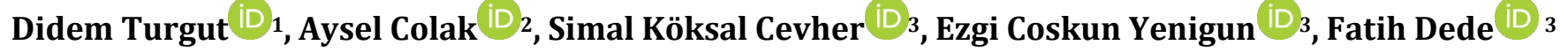 \\ 1 Baskent University Ankara Hospital, Department of Internal Medicine, Division of Nephrology, Ankara, Turkey \\ 2 The University of Health Sciences, Ankara City Hospital, Department of Pathology, Ankara, Turkey \\ 3 The University of Health Sciences, Ankara City Hospital, Department of Nephrology, Ankara, Turkey \\ Received: 23.12.2020; Revised: 10.02.2021; Accepted: 14.02.2021
}

\begin{abstract}
Objective: Kidney biopsy is essential to evaluate the activity of underlying kidney disease and the risk factors related to kidney disease progression. Glomerular morphometry is a simple but uncommonly used qualitative predictor of longterm kidney function. But it is mysterious if glomerular morphometry changes due to underlying glomerulonephritis. Measurement quantification is also necessary for reliable interpretation. We aimed to evaluate glomerular morphometry with glomerular area measurements quantitatively with digitally scanned slides in the primary glomerular diseases.
\end{abstract}

Methods: We retrospectively analyzed 198 patients with nephrotic syndrome that underwent kidney biopsy between 2017 and 2019. 48 patients enrolled into the study after the exclusion criteria. We measured the glomerular area as maximum, minimum, and mean areas, using image analysis software.

Results: Forty-eight kidney biopsies were analyzed retrospectively under three primary glomerular disease groups as IgA nephropathy (37.5\%), focal segmental glomerulosclerosis (29.2\%), and membranous glomerulonephritis (33.3\%). The glomerular area measured as maximum, minimum, and mean, were similar between 3 groups. The maximum glomerular area was negatively correlated with serum albumin and positively correlated with $24 \mathrm{hr}$ proteinuria $(\mathrm{r}=$ $0.592, \mathrm{p}=0.044$, and $\mathrm{r}=0.531, \mathrm{p}=0.022$ ) at the time of diagnosis. At the end of one year, maximum glomerular area was positively correlated with serum creatinine $(\mathrm{r}=0.385, \mathrm{p}=0.019)$ and negatively correlated with eGFR $(\mathrm{r}=-0.493$, $\mathrm{p}=0.043$ ).

Conclusions: At the time of diagnosis of glomerular diseases, maximum glomerular area measurement during the pathological assessment might be an additional marker to estimate the ultrastructure of the kidney and the clinical course of the disease.

Keywords: glomerular, area, proteinuria, morphometry, primary glomerulonephritis

DOI: $10.5798 /$ dicletip.887368

Correspondence / Yazıșma Adresi: Didem Turgut, Baskent University Ankara Hospital Department of Internal Medicine, Division of Nephrology Ankara, Turkey e-mail: dr.didem@gmail.com 


\section{Primer Glomerülonefritlerde Glomerül Alanın Dijital Patoloji Yazılımı ile Değerlendirilmesi}

Öz

Giriş: Böbrek biyopsisi, altta yatan böbrek hastalığını ve progresyona sebep olabilecek risk faktörlerini belirlemek için gereklidir. Glomerüler morfometri basit ancak kullanılmayan, uzun dönem böbrek fonksiyonları hakkında nitel bilgi veren bir yöntemdir. Ancak altta yatan glomerülonefrit tipine göre glomerüler morfometrinin değişip değişmediği bilinmemektedir. Güvenilir değerlendirme için de ölçümlerin standart olması gereklidir. Biz bu çalışmada, primer glomerüler hastalıklarda glomerül morfometresini dijital ortamda, standart bir şekilde, glomerüler alan ölçerek değerlendirmeyi hedefledik.

Yöntemler: 2017-2019 yılları arasında nefrotik sendrom tanısı ile böbrek biyopsisi yapılmış 198 hasta restrospektif olarak değerlendirildi. Dışlama kriterleri sonrasında 48 hasta çalışmaya dahil edildi. Glomerül alanı, maksimum, minimum ve ortalama alan ölçümü olarak bilgisayar programı kullanılarak tüm seri kesitlerde incelendi.

Bulgular: Kırksekiz böbrek biyopsinde, \% 37,5 hastada IgA nefropatisi, \% 33,3 memranöz glomerulonefrit, \% 29,2 hastada fokal segmental glomeruloskleroz tespit edildi. Üç grup arasında maksimum, minimum ve ortalama glomerül alanları benzerdi. Maksimum glomerül alanı tanı anındaki serum albumin ile negatif, 24 saatlik idrar protein miktarı ile pozitif korele bulundu $(r=-0,592$, $p=0,044$ ve $r=0,531, p=0,022)$. Tedavi sonrası birinci yılda, maksimum glomerül alanı serum kreatinin ile pozitif ( $r=0.385, p=0.019)$, GFR ile negatif korele bulundu $(r=0,493, p=0,043)$.

Sonuç: Glomerüler hastalıklarda tanı anındaki patolojik değerlendirmede maksimum glomerül alan ölçülmesi, böbreğin altyapısı ve hastalığın klinik gidişatı hakkında tahminde bulunmak için ek belirteç olabilir.

Anahtar kelimeler: glomerül alanı, proteinüri, glomerül morfometri, primer glomerülonefrit, sonlanım.

\section{INTRODUCTION}

A kidney biopsy in patients with suspected glomerular disease is essential to categorize the underlying disease and predict the clinical course $^{1}$. Histologic assessment and classification systems have a role in predicting future events, including response to immunosuppressive treatments ${ }^{2}$. Classification systems mainly depend on parameters like glomerular lesions, tubular atrophy, and interstitial fibrosis. Morphometric assessment of glomeruli (as glomerular area or volume) is not commonly used in this evaluation process. Glomerular area (GA) is correlated with various aspects of kidney function ${ }^{3,4}$. In the literature, there are studies related to GA and disease course with IgA nephropathy (IgAN) 5 , idiopathic membranous nephropathy (IMN) ${ }^{6}$, focal segmental glomerulosclerosis (FSGS) ${ }^{7}$, and diabetes mellitus (DM) ${ }^{8}$. But these studies are mainly related to the pediatric population or analyzed the GA with unstandardized methods. In this study, we measured GA with a digital pathology protocol in adult patients in serial sections of the biopsy specimen. The primary objective of the study was to analyze the GA under glomerular disease type with a quantitative method. The secondary goal was to investigate the correlation between GA, clinical course, and treatment response.

\section{METHODS}

\section{Patient Selection}

Patients with nephrotic syndrome (presence of protein excretion greater than $3.5 \mathrm{~g} / 24$ hours, hypoalbuminemia (less than $3 \mathrm{~g} / \mathrm{dl}$ ), and peripheral edema) ${ }^{8}$ that underwent kidney biopsies at the Ankara Bilkent City Hospital between 2017-2019 years were analyzed retrospectively. 198 patient records were reevaluated. Our patients were between 18-65 years old. Patients with DM and/or coronary heart disease (CHD) were not included in the study. Any patients with a moderately impaired renal function (estimated glomerular filtration rate (eGFR) $<60 \mathrm{~mL} / \mathrm{min} / 1.73 \mathrm{~m} 2$ ) at the time of the biopsy and those whose renal tissue specimens contained $<8$ glomeruli (globally 
sclerotic glomeruli not included) were carefully excluded. eGFR was calculated with CKD-EPI equation ${ }^{9}$. Kidney biopsies from patients with FSGS and membranous nephropathy (MN) but who probably have a secondary form (lupus nephritis, obesity, infection, or malignancyrelated) were excluded. At the end, 48 patients were enrolled in the study.

Patients' demographical and clinical data were obtained from the hospital's electronic records. At the time of diagnosis, body mass index (BMI), body surface area (BSA), serum creatinine ( $\mathrm{sCr}$ ), serum albumin, and 24-hour urine protein levels are assed. During follow-up period, 1styear $\mathrm{sCr}$, serum albumin, and 24-hour urine protein levels are analyzed to estimate the treatment response. Complete remission defined as proteinuria $<0.3 \mathrm{~g} / 24$ hours (uPCR $<300 \mathrm{mg} / \mathrm{g}(<30 \mathrm{mg} / \mathrm{mmol}))$. Partial remission defined as proteinuria $>0.3$ but $<3.5 \mathrm{~g} / 24$ hours or a decrease in proteinuria by at least $50 \%$ from the initial value and $<3.5 \mathrm{~g}$ per 24 hours. However, specific remission criteria due to underlying glomerulonephritis (GN) patterns are also carefully evaluated ${ }^{10}$. Supportive and immunosuppressive management of underlying glomerular diseases were assessed case-by-case on the route of recommended options of KDIGO ${ }^{10}$.

\section{Pathological Analysis}

All kidney tissue specimens were obtained by performing a percutaneous needle biopsy. In all cases, the diagnosis of primary GN was based on characteristic findings by light microscopy (sections stained with hematoxylin and eosin, Masson-Trichrome, Jones' silver impregnation, and periodic acid-Schiff) and immunofluorescence using standard protocols. For morphometry analysis, hematoxylin and eosin-stained specimens of selected patients according to exclusion criteria were scanned with the Leica Aperio CS2 image capture device. Under 20x magnification, digital slides were created. Virapath-2.1 (Virasoft Softare Inc.,
İstanbul, Turkey) software was used to transfer digital slides into the computer. The same pathologist analyzed the digital slides and only non-sclerotic glomeruli were examined. The quantitative measurement of the GA was done with the software. The total GA (from the outline of Bowman's capsule) was measured under the 10x magnifications in the following sections. All sections were carefully examined; all glomeruli were measured with the program separately. Maximum GA, minimum GA, and mean GA, according to the number of glomeruli, calculated automatically by the same software (Figure-1).

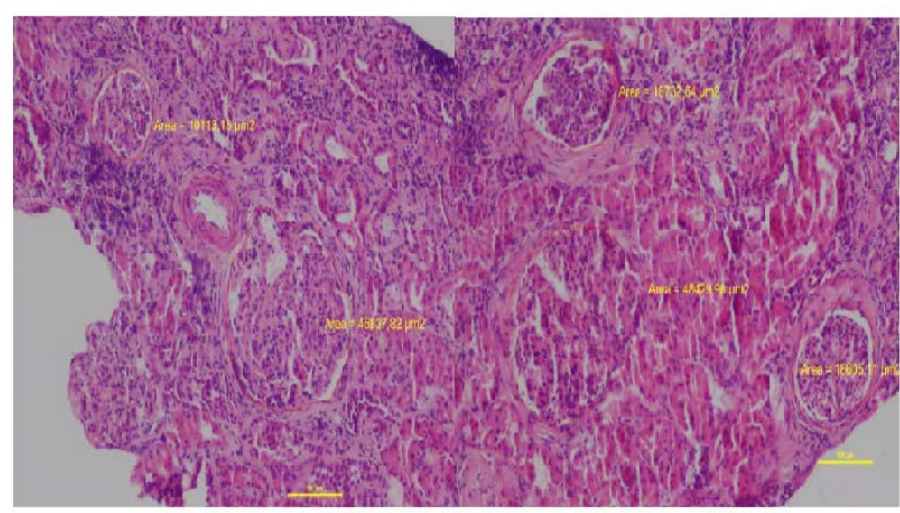

Figure 1: Measurement of glomerular area in different sections.

\section{Statistical Analysis}

The Kruskal-Wallis test and post-hoc analysis with the Tukey-Cramer test were used to analyze differences between groups. The MannWhitney U test was used where appropriate. Correlation coefficients were calculated using Spearmen's method. To find the factors affecting the treatment response (as no remission and partial remission/complete remission) logistic regression was used. Results were accepted as statistically significant if $\mathrm{p}<0.05$. All the data were analyzed using statistical software package (SPSS forWindows, Version 25.0, SPSS, USA).

\section{Ethical issues}

This study was approved by the institution's ethics committee and was carried out under the 
Declaration of Helsinki (Committee decision no: E1/098/2019; 24.10.2019). All participants provided informed consent for the use of excess renal biopsy tissue available after diagnostic examination for research purposes.

\section{RESULTS}

Forty-eight kidney biopsies were analyzed retrospectively due to inclusion criteria. Biopsies are classified in three groups as IgAN; $\mathrm{n}=18 \quad$ (37.5\%), FSGS; $\mathrm{n}=14 \quad$ (29.2\%), Membranous GN; $n=16$ (33.3\%). There was not any difference between groups for patients' age, BMI, and BSA. There was no gender difference between the groups. For all study groups, 15 (31\%) patients had hypertension (HT), 8 (17\%) of them in the IgAN, $5(10 \%)$ of them in the FSGS, and 2 (4\%) of them in the MGN groups. As immunosuppressive treatment, 6 (12.5\%) patients had cyclosporine, 4 (8.3\%) had cyclophosphamide and $2(4.16 \%)$ had tacrolimus. In laboratory measurements, for all patients $(\mathrm{n}=48)$, mean $\mathrm{sCr}$ was $0.88 \pm 0.39$ $\mathrm{mg} / \mathrm{dl}$, eGFR $97.0 \pm 24.5 \mathrm{ml} / \mathrm{min} / 1.73 \mathrm{~m} 2$, serum albumin $3.43 \pm 0.94 \mathrm{~g} / \mathrm{dl}$, and $24 \mathrm{hr}$ proteinuria $4735 \pm 1432 \mathrm{mg} /$ day, at the time of diagnosis. At the end of first year mean sCr was $1.31 \pm 0.92$ $\mathrm{mg} / \mathrm{dl}$, eGFR $93.8 \pm 31.8 \mathrm{ml} / \mathrm{min} / 1.73 \mathrm{~m} 2$, serum albumin $4.10 \pm 0.92 \mathrm{~g} / \mathrm{dl}$, and $24 \mathrm{hr}$ proteinuria $1174 \pm 817 \mathrm{mg} /$ day. At the end of 1st-year, 14 (29\%) had complete remission, $23(48 \%)$ had partial remission, and 11 (23\%) had no remission.

According to underlying glomerular disease, at the time of diagnosis, serum albumin was lower, and 24h urine protein was higher in MGN group regarding the IgAN group $(\mathrm{p}=0.012, \mathrm{p}=0.019)$. In 1st-year assessment, $\mathrm{sCr}$ and $24 \mathrm{~h}$ urine protein was higher in the FSGS group to the IgAN group $(p=0.004, p=0.031)$. The GA measured as maximum, minimum, and mean, were similar between groups $(p=0.179$, $\mathrm{p}=0.370, \mathrm{p}=0.632$ ). When we analyzed glomerular morphometry, whether patients had HT $(15 / 48)$ or not $(33 / 48)$, they were similar, respectively $(\mathrm{p}=0.627, \mathrm{p}=0.460$, $\mathrm{p}=0.185$ ) too. Demographic data and laboratory results are summarized in Table I.

Table I: Population characteristics and laboratory measurements according to underlying glomerular diseases

\begin{tabular}{|c|c|c|c|c|}
\hline & $\begin{array}{c}\operatorname{IgAN} \\
\mathrm{N}=18(37.5 \%)\end{array}$ & $\begin{array}{c}\text { FSGS } \\
\mathrm{N}=14(29.2 \%)\end{array}$ & $\begin{array}{c}\text { MGN } \\
\mathrm{N}=16(33.3 \%)\end{array}$ & $\mathbf{p}$ \\
\hline Age (years) & $45(18-60)$ & $42(20-65)$ & $40(18-65)$ & 0.123 \\
\hline Gender (F/M) & $9 / 9$ & $7 / 7$ & $8 / 8$ & \\
\hline BMI $\left(\mathrm{kg} / \mathrm{m}^{2}\right)$ & $30(20-38.7)$ & $31.4(19.7-38.2)$ & $26.2(18.8-38.7)$ & 0.227 \\
\hline \multicolumn{5}{|l|}{ Laboratory Data } \\
\hline $\mathrm{sCr}(\mathrm{mg} / \mathrm{dl})$ & $0.9(0.5-1.4)$ & $0.8(0.5-1.2)$ & $0.7(0.5-1.03)$ & 0.076 \\
\hline $\begin{array}{l}\text { eGFR } \\
\mathrm{ml} / \mathrm{min} / 1.73 \mathrm{~m} 2\end{array}$ & $84(60-112)$ & $100(64-129)$ & $112(69-145)$ & 0.122 \\
\hline $\begin{array}{l}\text { Serum albumin } \\
(\mathrm{g} / \mathrm{L})\end{array}$ & $4.0(3.2-4.7)$ & $3.1(1.4-4.7)$ & $3.0(1.3-4.3)$ & $0.012^{a}$ \\
\hline $\begin{array}{l}24 \mathrm{~h} \quad \text { proteinuria } \\
(\mathrm{mg} / \mathrm{d})\end{array}$ & $\begin{array}{c}2530 \\
(840-7000)\end{array}$ & $\begin{array}{c}3380 \\
(890-15700)\end{array}$ & $\begin{array}{c}5200 \\
(2039-14300)\end{array}$ & $0.019^{b}$ \\
\hline \multicolumn{5}{|l|}{ Pathological Data } \\
\hline $\begin{array}{l}\text { Glomerular } \\
\text { number (n) }\end{array}$ & $9(8-14)$ & $9(8-18)$ & $9(8-15)$ & 0.406 \\
\hline $\begin{array}{l}\text { Maximum GA } \\
\left(\mu \mathrm{m}^{2}\right) \times 10^{3}\end{array}$ & $40.3(22.9-81.6)$ & $48.9(23.1-71.4)$ & $38.9(28-51.9)$ & 0.179 \\
\hline $\begin{array}{l}\text { Minimum GA } \\
\left(\mu \mathrm{m}^{2}\right) \times 10^{3}\end{array}$ & $16.7(6.0-25.6)$ & $14.6(8.9-28)$ & $15.2(10.2-25.6)$ & 0.370 \\
\hline $\begin{array}{l}\text { Mean GA } \\
\left(\mu \mathrm{m}^{2}\right) \times 10^{3}\end{array}$ & $28.9(16.7-43.4)$ & $31.1(17.1-39.9)$ & $27.9(18.7-36.9)$ & 0.632 \\
\hline $\begin{array}{l}\text { Glomerular } \\
\text { number (n) }\end{array}$ & $9(8-14)$ & $9(8-18)$ & $9(8-15)$ & 0.406 \\
\hline
\end{tabular}

BMI: Body mass index, BSA: Body surface area, eGFR: estimated glomerular filtration rate, FSGS: Focal segmental glomerulosclerosis, HT: Hypertension, IgAN: IgA nephropathy, MGN: Membranous glomerulonephritis, sCr: serum creatinine. Data presented as median and (min-max). a, b IgAN and MGN are statistically different in between. 
In correlation analysis of all groups $(n=48)$, only maximum GA was negatively correlated with serum albumin and positively correlated with $24 \mathrm{hr}$ proteinuria $(\mathrm{r}=-0.592, \mathrm{p}=0.044$, and $\mathrm{r}=0.531, \mathrm{p}=0.022$ ) at the time of diagnosis. At the end of one year, maximum GA was positively correlated with serum creatinine $(\mathrm{r}=0.385$, $\mathrm{p}=0.019$ ) and negatively correlated with eGFR ( $r=-0.493, p=0.043$ ). But not correlated with the serum albumin and proteinuria at the end of 1 st year. None of laboratory or glomerular measurement type was statistically significant to explain remission state (as no remission and partial remission /complete remission) at the end of 1st year in the logistic regression analysis.

\section{DISCUSSION}

The present study has two main findings. First, according to underlying glomerular disease, the maximum GA did not differ. Second, the maximum GA was correlated with hypoalbuminemia and proteinuria at the time of diagnosis, and serum creatinine and eGFR at the end of the 1st year. We carefully excluded patients with secondary GN, DM, CAD, or decreased eGFR that would end with glomerular hemodynamic and structural changes. None of our patients were obese. Median age, female/male ratio, BMI, and BSA were similar regarding the underlying primary disease as IgAN, FSGS, and MGN.

It is known that glomerular enlargement is related to increased metabolic demands or decreased renal mass. But the mechanism under the expansion of the glomerulus is not that simple. Glomerular cell injury type also affects the glomerular morphology ${ }^{7}$. In an experimental study of five-sixths of nephrectomized rats with proteinuria, She et al. found that glomerular hypertrophy is related to mesangial cell proliferation and progressive increase of the mesangial matrix. It was a pathological process rather than a compensatory mechanism ${ }^{11}$. In humans, studies are generally related to obesity-related glomerular enlargement. Kambham et al. reported in 2011 that obesity-related glomerulomegaly with or without FSGS, associated with microalbuminuria beyond the increased metabolic demands ${ }^{12}$. Wu et al. analyzed the expression of inflammatory genesin the glomeruli- in obese patients with proteinuria. And they found that glomerular enlargement was probably related to chronic inflammation ${ }^{13}$. Glomerular injury type is also associated with the mechanism of enlarged $\mathrm{GA}^{14,15}$, and the progression of injury, in turn, affects the glomerular size ${ }^{16}$. Increased glomerular size in DM as a result of compensatory hypertrophy ${ }^{8}$, and decreased size in the course of senescence ${ }^{17}$ are known facts. But in the course of proteinuria, we do not know whether the underlying disease or proteinuria itself directly affects the ultrastructure. In our study, maximum GA, minimum GA, and mean GA were similar for the primary glomerular disease type. But in correlation analysis, maximum GA was the only measurement related to low serum albumin and high proteinuria. Maximum GA, as an indicator of enlarged glomerulus, might represent ultrastructure problems of kidney like podocyte injury. Or heavy proteinuria itself cause glomerular enlargement at the time of diagnosis of the glomerulonephritis. None of our patients were obese that would cause glomerulus enlargement secondarily. Although our subject number is low, it is likely to speculate that glomerular size is not only affected by the injury site of primary disease but also from proteinuria itself.

In other studies of renal ablation models, it was also suggested that the glomerular enlargement precedes the development of renal scarring18,19. It is reported that some injured glomeruli increase in size before they sclerosed or collapsed $^{20}$. This theory may be related to low nephron number too. Without any apparent 
renal dysfunction, nephron number in healthy people may vary. And it is shown that low nephron number is associated with poor outcomes of glomerular diseases ${ }^{21}$. It is not clear GA represents the nephron number of the whole kidney. But as we found in our study, increased glomerular size would be a primary step toward glomerulosclerosis. And our results indirectly support the idea that GA may be used as a marker of kidney nephron capacity. The morphometry might be a predictor for renal survival in the course of primary GN.

For histological sclerosis assessment, not only counting injured glomerulus but also enlargement of glomerulus should be used as an alarming sign of bad renal outcome in the preinjury period. Unfortunately, there is not a standardized measurement method for the assessment of GA. The Weibel and Gomez method $^{22}$ or mean planar area (MPA) measurement ${ }^{3}$ are used common methods. Weibel and Gomez estimates GA from a single histological section that cannot quantify the variation in the size of the glomerulus. MPA allows serial sectioned measurement of the tissue and identify the most significant profile for each glomerulus. But pathologists should keep in mind that examination of enlarged glomerulus concerning normal and sclerosing/collapsing glomerulus as maximum GA measurement may facilitate wrong measurement of glomerular size. In our study, measurements were based on MPA using digital pathology software. We measured all glomeruli in each section, and automatically measured the maximum and the minimum GA with the program. The mean GA was measured from all glomeruli which were examined for the same specimen. In this way, our study is unique that measures the glomerular size in very standardized way without any subjective assessment.

In long-term prognosis prediction studies, morphologic assessment of glomeruli was used to predict GFR loss, or 10-year renal function outcomes in several glomerular diseases 4 . Maximum GA was investigated as a prognostic indicator in IgAN, FSGS, and DM $23,24,8$ beyond the routine classification algorithms. Kataoka et al. revealed in their study that including maximum glomerular diameter in the Oxford classification of IgAN might increase its strength in the clinical setting ${ }^{25}$. Tsuboi and et al. evaluated glomerular density (GD) (inversely correlated with glomerular area) in 98 IgAN patients. And they displayed that low GD is related to enhanced risk for progression although interstitial fibrosis and degree of glomerulosclerosis were not independent predictors ${ }^{26}$. Our findings about 1st year serum creatinine and eGFR and GA correlation coincides with these findings. And also with more reliable measurement method, the idea was strengthened.

Our study has some limitations. Low subject number in the disease groups may empower the primary disease-related glomerular enlargement and related analysis. And in the literature, it is not apparent the exact cut-off value of enlarged glomerular diameter, which would cause unstandardized analysis of glomerular morphometry.

In conclusion, in the early period, maximum GA may be a marker of worse ultrastructural problems of the kidney. Enlarged glomeruli might estimate clinical course irrespective of underlying glomerular pathology. Using digital pathology software minimizes the pathologist related subjective measurements. With a high number of subjects, this finding should be optimized.

The abstract has been presented in International Society of Nephrology/WCN2020 as a poster presentation (Poster No: SUN-381. March 2020 Kidney International Reports 5(3): S355-S356 DOI: 10.1016/j.ekir.2020.02.920)

Ethical Committee Approval: This study was approved by the institution's ethics committee 
and was carried out under the Declaration of Helsinki (Committee decision no: E1/098/2019; 24.10.2019). All participants provided informed consent for the use of excess renal biopsy tissue available after diagnostic examination for research purposes.

Declaration of Conflicting Interests: The authors declare that they have no conflict of interest.

Financial Disclosure: No financial support was received.

\section{REFERENCES}

1. Aydin E, Aydin F.Y, Yilmaz E.D, Alabalik U. Böbrek Biyopsilerinin Histopatolojik Değerlendirilmesi: Tek Merkez Yedi Yıllık Deneyim. Dicle Tıp Dergisi. 2020; 47: 417-22.

2. Floege J, Barbour J.B, Cattran D. C et al. Management and treatment of glomerular diseases (part 1): conclusions from a Kidney Disease: Improving Global Outcomes (KDIGO) Controversies Conference. Kidney Int. 2019; 95: 268-80.

3. Pagtalunan ME, Drachman JA, Meyer TW. Methods for estimating the volume of individual glomeruli. Kidney Int. 2000; 57: 2644-49.

4. Lemley KV, Bagnasco SM, Nast CC, et al. Morphometry Predicts Early GFR Change in Primary Proteinuric Glomerulopathies: A Longitudinal Cohort Study Using Generalized Estimating Equations. PLoS ONE. 2016; 11: e0157148.

5. Lemley KV, Lafayette RA, Derby G, et al. Prediction of early progression in recently diagnosed IgA nephropathy. Nephrol Dial Transplant. 2008; 23: 213-22.

6. Tsuboi N, Kawamura T, Miyazaki Y, et al. Low glomerular density is a risk factor for progression in idiopathic membranous nephropathy. Nephrol Dial Transplant. 2011; 26:3555-60.

7. Fogo AB. Glomerular hypertension, glomerular growth and progression of renal diseases. Kidney Int. 2000; 57: 15-21.

8. Kroustrup J.P, Gundersen H.G.J, and Osterby R. Glomerular Size and Structure in Diabetes Mellitus
Il, Early Enlargement of the Capillary Surface. Diabetologia. 1977; 13: 207-10.

9. Kelepouris E, Rovin BH. Overview of heavy proteinuria and the nephrotic syndrome. UpToDate. Retrieved August 28, 2019.

10. Kidney Disease: Improving Global Outcomes (KDIGO) Glomerulonephritis Work Group. KDIGO clinical practice guideline for glomerulonephritis. Kidney Int Suppl. 2012; 2: 139-274.

11. Shea SM, Raskova J, Morrison AB. A stereologic study of glomerular hypertrophy in the subtotally nephrectomized rat. Am J Pathol. 1978; 90: 201-10.

12. Kambham N, Markowitz GS, Valeri AM, et al. Obesity-related glomerulopathy: an emerging epidemic. Kidney Int. 2001; 59: 1498-509.

13. Wu Y, Liu Z, Xiang Z, et al. Obesity-related glomerulopathy: insights from gene expression profiles of the glomeruli derived from renal biopsy samples. Endocrinology. 2006; 147: 44-50.

14. Fries JWU, Sandstrom DJ, Meyer TW, et al. Glomerular hypertrophy and epithelial cell injury modulate progressive glomerulosclerosis in the rat. Lab Invest. 1989; 60: 205-18.

15. Daniels BS, Hostetter TH: Adverse effects of growth in the glomerular microcirculation. Am J Physiol. 1990; 258: 1409-16.

16. Grond J, Beukers JYB, Schilthuis MS, et al. Analysis of renal structural and functional features in two rat strains with a different susceptibility to glomerular sclerosis. Lab Invest. 1986; 4: 77-85.

17. Fogo A, Ichikawa I: Evidence for a pathogenic linkage between glomerular hypertrophy and sclerosis. Am J Kidney Dis. 1991; 17: 666-9.

18. Brenner, BM. Nephron adaptation to renal injury or ablution. Am. J. Physiol. 1985; 49: 324-37.

19. Olson JL, Heptinstall RH. Nonimmunologic mechanisms of glomerular injury. Lab Invest. 1988 Nov; 59: 564-78.

20. Kataoka H, Mochizuki T, Nitta K. Large Renal Corpuscle: Clinical Significance of Evaluation of the Largest Renal Corpuscle in Kidney Biopsy Specimens. Contrib Nephrol. 2018; 195: 20-30. 
21. Hoy WE, Douglas-Denton RN, Hughson MD, et al. stereological study of glomerular number and volume: preliminary findings in a multiracial study of kidneys at autopsy. Kidney Int Suppl. 2003; 2: 317.

22. Weibel ER, Gomez DM. A principle for counting tissue structures on random sections. J Appl Physiol. 1962; 3; 17:343-8.

23. Kataoka H, Ohara M, Honda K, et al. Maximal glomerular diameter as a 10-year prognostic indicator for IgA nephropathy. Nephrol Dial Transplant. 2011; 0: 1-7.

24. D. Hughson M, Johnson $\mathrm{K}$, J. Young $\mathrm{R}$, et al. Bertram. Glomerular Size and Glomerulosclerosis:
Relationships to Disease Categories, Glomerular Solidification, and Ischemic Obsolescence. Am J Kidney Dis. 2002; 39: 679-88.

25. Kataoka H, Moriyama $\mathrm{T}$, Manabe $\mathrm{S}$, et al. Maximum Glomerular Diameter and Oxford MEST-C Score in IgA Nephropathy: The Significance of TimeSeries Changes in Pseudo-R2 Values in Relation to Renal Outcomes. J Clin Med. 2019; 2; 8. E2105. doi: $10.3390 /$ jcm8122105.

26. Tsuboi N, Kawamura T, Koike K, et al. Glomerular density in renal biopsy specimens predicts the longterm prognosis of IgA nephropathy. Clin J Am Soc Nephrol. 2010; 5: 39-44. 